\title{
Subcellular distribution and glycosylation pattern of androgen receptor from sheep omental adipose tissue
}

\author{
J P McCann ${ }^{1}$, J S Mayes, G R Hendricks, J B Harjo \\ and $\mathbf{G} \mathbf{H}$ Watson \\ College of Osteopathic Medicine, Oklahoma State University, 1111 West 17th Street, Tulsa, Oklahoma 74107-1898, USA \\ ${ }^{1}$ College of Veterinary Medicine, Oklahoma State University, Stillwater, Oklahoma 74078-0343, USA \\ (Requests for offprints should be addressed to G H Watson)
}

\begin{abstract}
Sex steroids are known to have an influence on the distribution, metabolism and accretion of adipose tissue. These steroids carry out their function via specific receptors. We have previously reported the presence of oestrogen and progesterone receptors in sheep adipose tissues. In this study, we have tested the subcellular distribution of androgen receptor (AR) in sheep omental adipose tissue. Subcellular fractions - microsomes, plasma membrane and nuclei-cell debris - were isolated by differential and sucrose gradient centrifugation and confirmed by electron microscopy. The AR was determined in each fraction by Western blot analyses. As anticipated, the receptor was found in the cytosolic fraction, but a high concentration was also present in the microsomal fraction, a lesser amount in the plasma membrane fraction, and only a small amount was left in the nuclei-cell debris fraction. Two minor immunostaining bands with approximate molecular weights of 250 and $140 \mathrm{kDa}$ and a major band
\end{abstract}

at $110 \mathrm{kDa}$ were detected in the cytosolic fraction, but only the $110 \mathrm{kDa}$ band was detected in the membrane fractions. A $104 \mathrm{kDa}$ band was observed on occasion and believed to be a degradation product.

The cytosolic isoforms were tested for sensitivity to glycosidases. This treatment resulted in a decrease in the amount of the 250 and $140 \mathrm{kDa}$ bands. To substantiate that the 250 and $140 \mathrm{kDa}$ isoforms were glycoproteins, the cytosolic fraction was chromatographed on Concanavalin A-Sepharose. The $110 \mathrm{kDa}$ band was eluted in the $0.4 \mathrm{M}$ $\mathrm{KCl}$ salt wash while the 250 and $140 \mathrm{kDa}$ bands were eluted with $\alpha$-methylmannoside. Treatment of the glycoprotein ( $\alpha$-methylmannoside) peak with glycosidases converted the 250 and $140 \mathrm{kDa}$ bands to the $110 \mathrm{kDa}$ band. These data confirm the presence of AR in subcellular fractions of adipose tissue and suggest that it exists in various glycosylated isoforms.

Journal of Endocrinology (2001) 169, 587-593

\section{Introduction}

Obesity is a risk factor for non-insulin-dependent diabetes, cardiovascular disease, some types of cancer, and certain reproductive and metabolic disorders (Bray 1996). This risk generally relates more to the central (abdominal, omental) male distribution pattern of fat than to the amount of fat. Men have a more central accumulation of fat, whereas women have a more gluteal/femoral accumulation (Bjorntorp 1990). Men also have a higher incidence of cardiovascular disease than women, and menopause in women increases the incidence of cardiovascular disease and the central distribution of adipose tissue (Tchernof \& Poehlman 1998). This would suggest a role for sex steroid hormones in the regulation of adipose tissue distribution and in risk factors for certain disorders. It is generally held that androgens may be a member of key hormones that regulate fat accumulation in central depots because androgenization increases central stores of fat in men (Bjorntorp 1990), in women with polycystic ovary syndrome (Rebuffe-Scrive et al. 1989) and in animal models (York 1996). It is unclear whether the role of androgens in adipose tissue accretion is direct or indirect. If it is a direct effect, androgen receptor (AR) should be present in adipose tissue. In support of this Pedersen et al. (1996) reported the presence of AR in human adipose tissue.

We have been studying obesity in a sheep model (McCann et al. 1992). Oestrogen receptor (ER) was present in adipose tissues from these animals (Watson et al. 1993) and the ER appeared to be functional as oestrogen treatment of ovariectomized ewes resulted in the up-regulation of progesterone receptor (PR) in adipose tissues (Mayes et al. 1996). This study is our initial investigation into the presence of $\mathrm{AR}$ in omental adipose tissue from female sheep. 


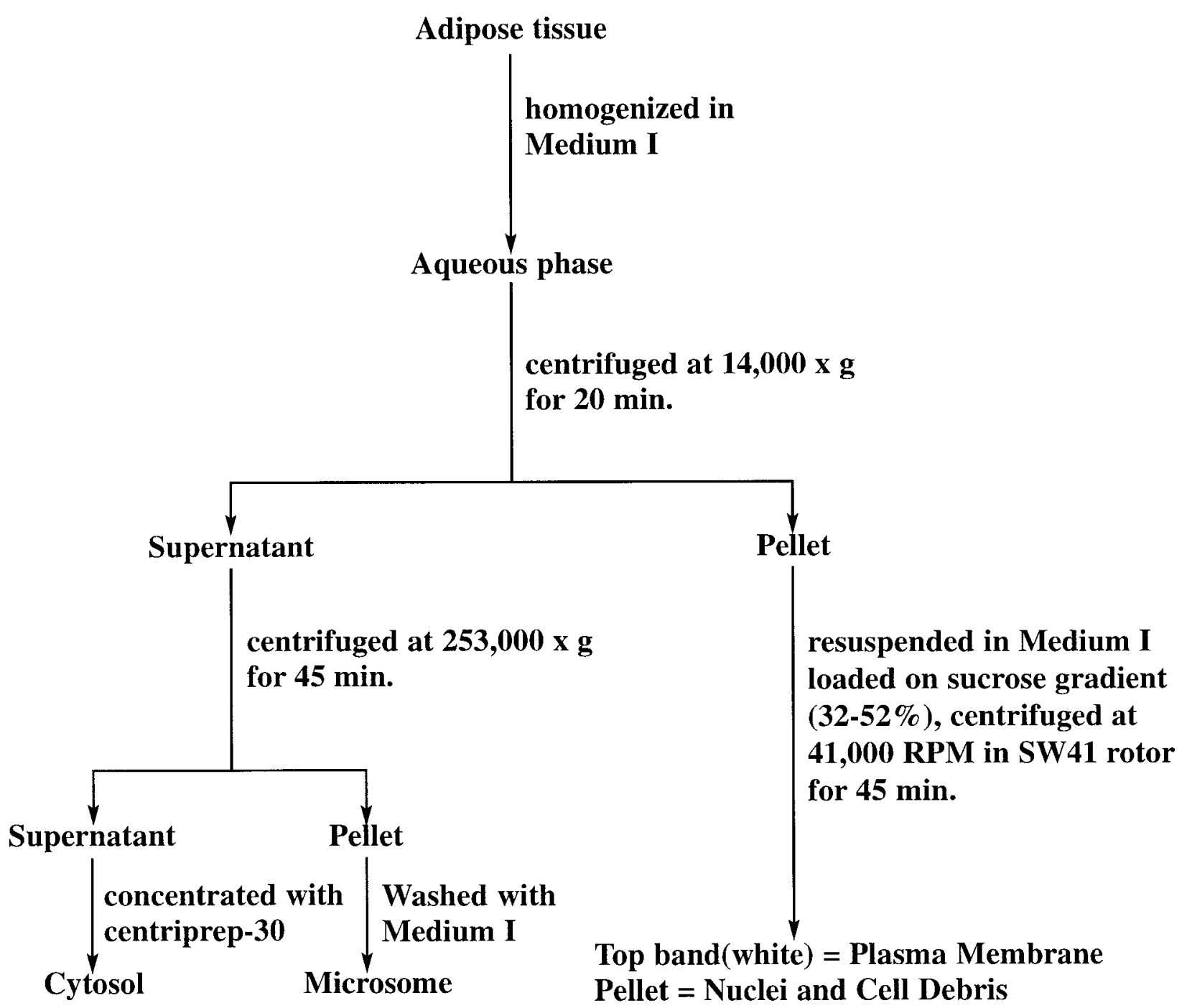

Figure 1 Diagram for isolation of subcellular fractions from omental adipose tissue.

\section{Materials and Methods}

Animals and preparation of tissues

All procedures were approved by the Institution Animal Use and Care Committee, Oklahoma State University. Four adult Dorset ewes were ovariectomized and maintained a minimum of 30 days to decrease the endogenous steroids before experiments were begun. Animals were then treated for 8-12 days with subcutaneous oestradiol$17 \beta$ implants to maintain physiological concentrations of oestrogen. At necropsy, animals were anaesthetized deeply with pentobarbital and exsanguinated. Tissues were removed expediently, frozen in liquid nitrogen and stored at $-80^{\circ} \mathrm{C}$.

\section{Isolation of subcellular fractions}

Omental adipose tissue $(1 \mathrm{~g} / \mathrm{ml})$ was homogenized at $4{ }^{\circ} \mathrm{C}$ with Medium I (0.25 M sucrose, $1 \mathrm{mM}$ EDTA, $10 \mathrm{mM}$
Tris- $\mathrm{HCl}, \mathrm{pH} 7 \cdot 4)$ which contained protease inhibitors (aminoethyl-benzenesulfonyl fluoride, leupeptin, bacitracin, aprotinin and pepstatin; Watson et al. 1993). Unless otherwise stated, all chemicals and reagents were obtained from Sigma (St Louis, MO, USA). The aqueous phase was removed with a Pasteur pipette and the subcellular fractions - microsomes, plasma membrane and nuclei-cell debris - isolated by differential and sucrose gradient centrifugation as shown in Fig. 1. Microsomes were isolated by differential centrifugation (St John et al. 1991). Plasma membrane and nuclei-cell debris fractions were isolated by sucrose gradient centrifugation (Lewis et al. 1981). Electron micrographs of the microsomal and plasma membrane pellets were very similar in appearance to those reported by Steinsapir et al. (1990) and electron micrographs of the nuclei-cell debris pellet showed mainly debris with very few intact nuclei. The 
electron micrographs of these pellets did not show any major contamination by mitochondria or peroxisomeslysosomes. Uterine cytosol was prepared from each animal to serve as a control.

\section{Western blot analyses}

Briefly, denatured proteins were separated by SDS-PAGE using $7 \cdot 5 \%$ gels in the Mini-protean II system (Bio-Rad, Hercules, CA, USA). Prestained protein markers (Bio$\mathrm{Rad}$ ) were used as standards. Proteins were transferred from the polyacrylamide gels to nitrocellulose membranes by electro-blotting in a Trans Blot apparatus (Bio-Rad) at a $100 \mathrm{~V}$ setting for $1 \mathrm{~h}$. After blocking with $3 \%$ gelatin, the membranes were then immunostained with rabbit polyclonal anti-AR (PG-21) as the first antibody. This was followed with goat anti-rabbit IgG-alkaline phosphatase conjugate as the second antibody. Alkaline phosphatase colour development solution was added and incubated at room temperature to visualize the AR specific bands. Image analyses were performed on a GS 710 calibrated imaging densitometer (Bio-Rad).

The PG-21 antibody and the 21 amino acid peptide immunogen were gifts from Dr G Greene, University of Chicago, Chicago, IL, USA (Prins et al. 1991). This antibody was produced by immunizing rabbits with a peptide corresponding to the N-terminal 21 amino acids of rat and human AR. It is specific for AR and will not cross-react with ER, PR or glucocorticoid receptor. By Western blot analysis, the antibody reacts with a $110 \mathrm{kDa}$ band which is the molecular weight of AR. Competition experiments with the 21 amino acid peptide immunogen inhibits the immunostaining for AR. Using the abovementioned criteria, we feel that the immunostaining which we observed in extracts of omental adipose tissue was specific for AR. In beginning experiments, we also used two other AR antibodies, U407 and R489, which were gifts from Dr M McPhaul, University of Texas Southwestern Medical Center, Dallas, TX, USA (Husmann et al. 1990). The R489 antibody did crossreact with the three cytosolic AR isozymes from sheep omental adipose tissue, while the U407 antibody did not cross-react. The PG-21 antibody was employed in all experiments reported in this article.

\section{Concanavalin A chromatography}

For binding to Concanavalin A (Con A), omental adipose tissue was extracted with $0 \cdot 1 \mathrm{M}$ acetate buffer, $\mathrm{pH} 6 \cdot 0$, containing $1 \mathrm{mM} \mathrm{MgCl}_{2}, 1 \mathrm{mM} \mathrm{MnCl}$ and $1 \mathrm{mM} \mathrm{CaCl}_{2}$ with protease inhibitors. The aqueous phase was removed with a Pasteur pipette and centrifuged at $253000 \mathrm{~g}$ for $45 \mathrm{~min}$. Supernatant (cytosolic fraction) was added to a $4 \mathrm{ml}$ Con A-Sepharose 4B column. After washing with $0 \cdot 4 \mathrm{M} \mathrm{KCl}$ in the acetate buffer containing the divalent metals and protease inhibitors, the glycoproteins were eluted with $0.5 \mathrm{M} \alpha$-methylmannoside in the acetate buffer with protease inhibitors, but without divalent metals. Fractions were pooled, concentrated with Centriprep-30 and analyzed for AR by Western blot.

\section{Treatment with endoglycosidase F/N-glycosidase F}

The cytosolic fraction or the glycoprotein peak from the Con A column was incubated overnight $(18 \mathrm{~h})$ with $0 \cdot 4$ units endoglycosidase $\mathrm{F} / \mathrm{N}$-glycosidase $\mathrm{F}$ (Sigma) at $37^{\circ} \mathrm{C}$. An equal volume of the denaturing buffer for gel electrophoresis was added and Western blot analysis for AR was performed.

\section{Results}

A representative Western blot analysis of AR from subcellular fractions of sheep omental adipose tissue is shown in Fig. 2. The cytosolic AR showed isoforms with molecular weights of approximately 250, 140 and $110 \mathrm{kDa}$ (Fig. 2A). An immunostaining band of approximately $104 \mathrm{kDa}$ was sometimes observed below the $110 \mathrm{kDa}$ band. The $110 \mathrm{kDa}$ immunostaining band for AR was also present in the microsomal fraction and to a lesser extent in the plasma membrane fraction while very little remained in the nuclei-cell debris fraction (Fig. 2B). When the cytosolic fraction was treated with endoglycosidase $\mathrm{F} / \mathrm{N}$ glycosidase $\mathrm{F}$, the 250, 140 and $110 \mathrm{kDa}$ bands decreased in intensity, while the $104 \mathrm{kDa}$ band increased (Fig. 3). Image analyses showed the quantity (intensity $\times \mathrm{mm}$ ) of the $250 \mathrm{kDa}$ band decreased from 0.313 to $0 \cdot 070$, the $140 \mathrm{kDa}$ band decreased from 0.288 to 0.112 and the $110 \mathrm{kDa}$ band decreased from $0 \cdot 448$ to $0 \cdot 316$, while the $104 \mathrm{kDa}$ band increased from $0 \cdot 182$ to $0 \cdot 315$. This suggested that these bands were glycoproteins. To confirm this possibility, a cytosolic fraction was chromatographed on Con A-Sepharose (Fig. 4A). The $110 \mathrm{kDa}$ band was eluted in the salt wash while the 250 and $140 \mathrm{kDa}$ bands were eluted with $\alpha$-methylmannoside (Fig. 4B). Subsequent treatment of the $\alpha$-methylmannoside (glycoprotein) fraction with endoglycosidase $\mathrm{F} / \mathrm{N}$-glycosidase $\mathrm{F}$ resulted in the conversion of the 250 and $140 \mathrm{kDa}$ bands to the $110 \mathrm{kDa}$ band (Fig. 5). Image analyses showed the quantity (intensity $\times \mathrm{mm}$ ) of the $250 \mathrm{kDa}$ band decreased from 0.604 to 0.095 and the $140 \mathrm{kDa}$ band decreased from $0 \cdot 409$ to $0 \cdot 286$, while the $110 \mathrm{kDa}$ band increased from $0 \cdot 133$ to $0 \cdot 404$.

\section{Discussion}

Androgens affect the metabolism, deposition and distribution of fat (Vermeulen et al. 1999). However, it is not known whether these affects on adipose depots are direct 


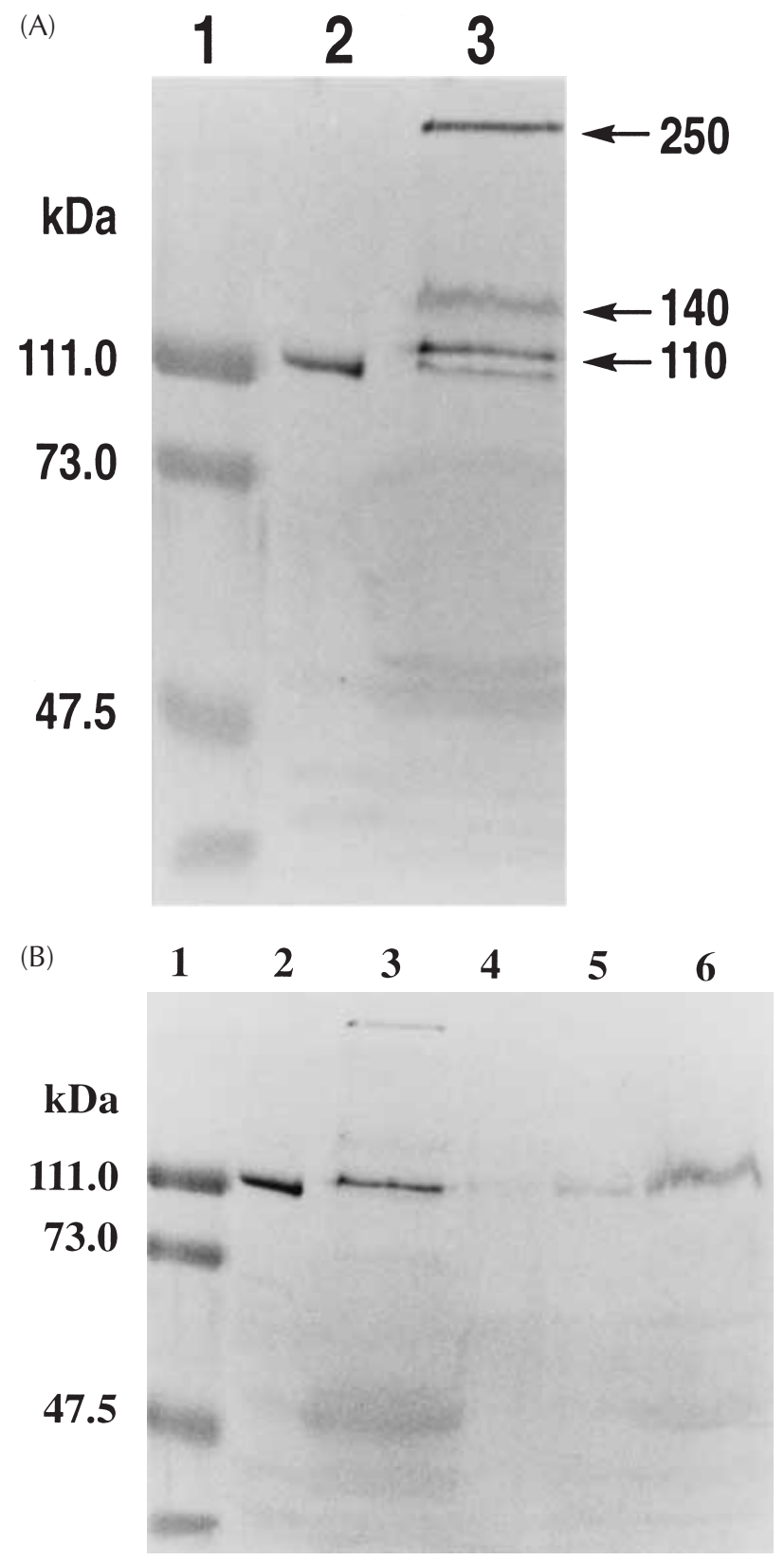

Figure 2 (A) Western blot analysis of AR in the cytosolic fraction from sheep omental adipose tissue. Lane 1: prestained protein standards (low range) with molecular weight on left. Lane 2: cytosolic fraction $(21.8 \mu \mathrm{g}$ protein) from uterine tissue. Lane 3 : cytosolic fraction ( $800 \mu \mathrm{g}$ protein) from omental adipose tissue. (B) Western blot analysis of AR in subcellular fractions from sheep omental adipose tissue. Lane 1: prestained protein standards (low range) with molecular weight on left. Lane 2: cytosolic fraction (21.8 $\mu$ g protein) from uterine tissue. Lane 3 : cytosolic fraction (800 $\mu$ g protein) from omental adipose tissue. Lane 4: nuclear fraction from $6 \mathrm{~g}$ omental adipose tissue. Lane 5: plasma membrane fraction from $6 \mathrm{~g}$ omental adipose tissue. Lane 6: microsomal fraction from $6 \mathrm{~g}$ omental adipose tissue.

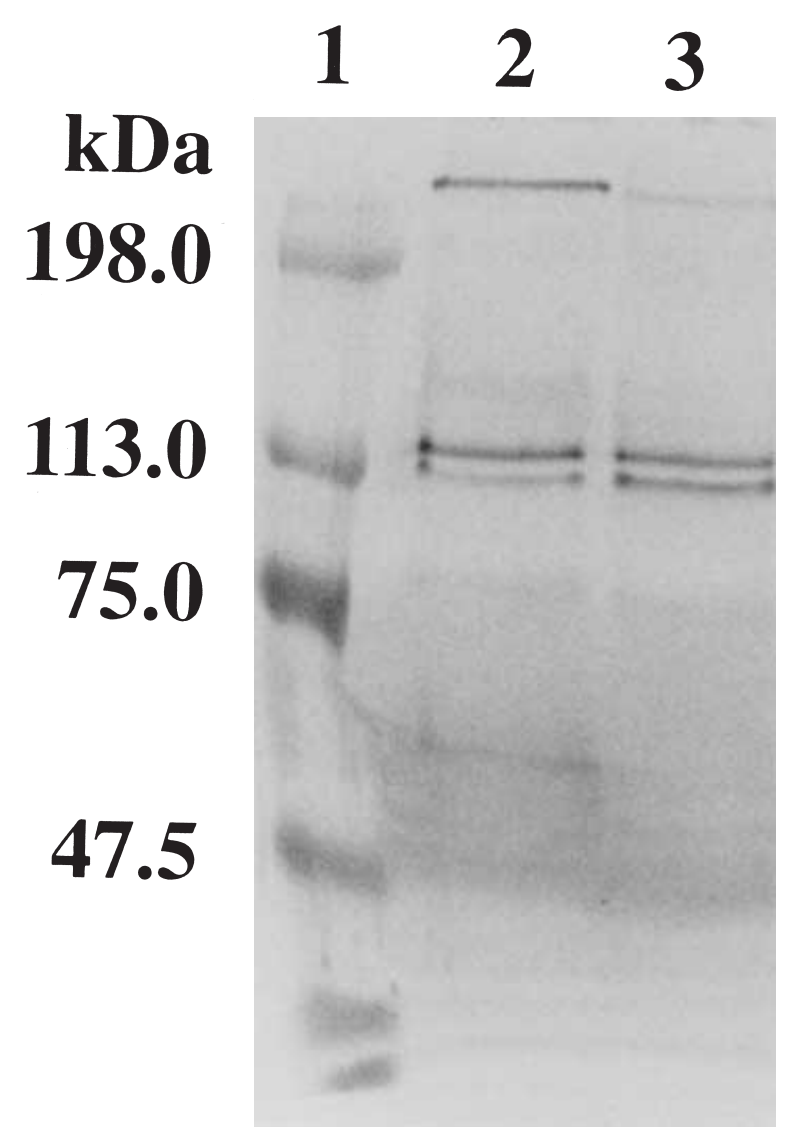

Figure 3 Treatment of cytosolic fraction with endoglycosidase $\mathrm{F} / \mathrm{N}$-glycosidase $\mathrm{F}$ followed by Western blot analysis for androgen receptor. Lane 1: prestained protein standards (broad range) with molecular weight on left. Lane 2: cytosolic fraction $(800 \mu \mathrm{g}$ protein) from omental adipose tissue incubated without glycosidases. Lane 3: cytosolic fraction (800 $\mu \mathrm{g}$ protein) from omental adipose tissue incubated with glycosidases.

or indirect. If they are direct, an AR should be present in the tissues. Sjogren et al. (1995) used ligand-binding assays to show androgen binding to isolated nuclei from adipose depots of male rats. Pedersen et al. (1996) employed ligand binding and RT-PCR to demonstrate the presence of AR in adipocytes from subcutaneous abdominal fat from patients undergoing intra-abdominal surgery. Our initial Western blot results showed the presence of AR protein in the cytosolic fraction of sheep gluteal, omental and perirenal adipose tissues. As abdominal obesity appears to be associated with androgen action, we have concentrated on the subcellular distribution and apparent glycosylation pattern of $\mathrm{AR}$ in omental adipose tissue. In omental adipose tissue the receptor was found mainly in the cytosolic and microsomal fractions with a smaller amount in the plasma membrane fraction, while very little remained in the nuclei-cell debris fraction. It is generally accepted that, with homogenization of tissues in hypotonic buffers, many steroid receptors are released from the 


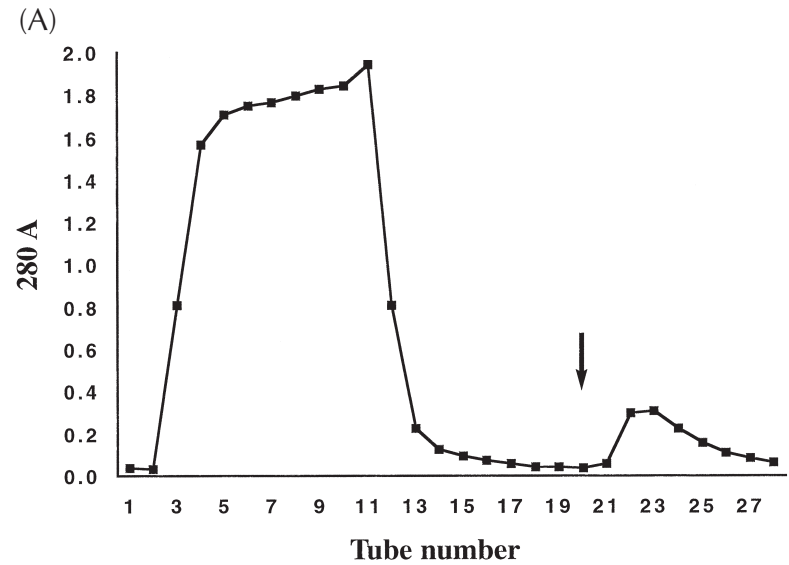

(B)

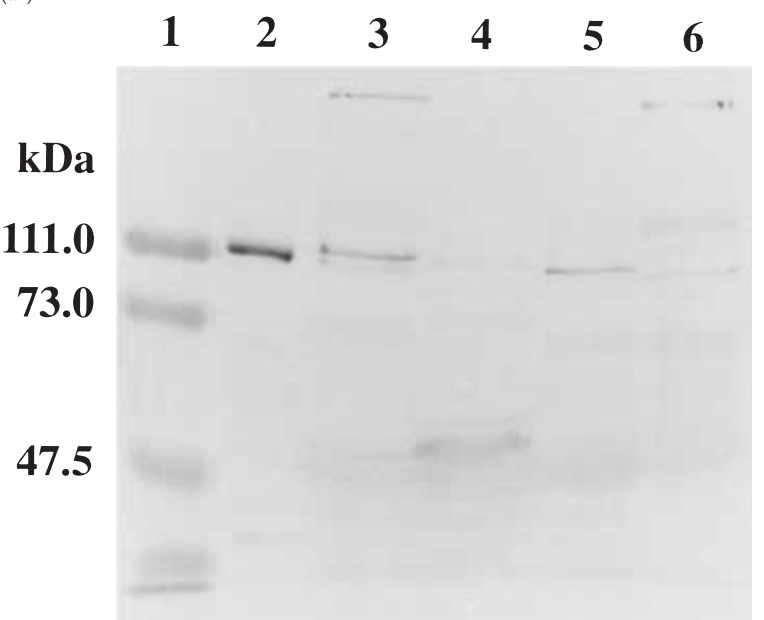

Figure 4 (A) Con A chromatography of cytosolic fraction from omental adipose tissue. Tubes $3-11=$ peak 1 (unbound fraction). Tubes $12-21=0 \cdot 4 \mathrm{M} \mathrm{KCl}$ salt wash. Tubes $22-28=$ peak 2 (elution with $\alpha$-methylmannoside). (B) Western blot analysis of AR in fractions from Con A chromatography. Lane 1: prestained protein standards (low range) with molecular weight on left. Lane 2: cytosolic fraction $(21 \cdot 8 \mu \mathrm{g}$ protein) from uterine tissue. Lane 3: cytosolic fraction ( $800 \mu \mathrm{g}$ protein) from omental adipose tissue. Lane 4: peak 1 (unbound fraction) from Con A column. Lane 5: salt wash from Con A column. Lane 6: peak 2 $(\alpha$-methylmannoside fraction) from Con A column.

nucleus and move into the cytoplasm. The reason for the presence of receptor in the microsomes is not clear. Earlier work by Watson \& Muldoon (1985) showed the presence of a sex steroid receptor (ER) in rat uterine microsomes and Steinsapir et al. (1990) showed androgen-binding sites in endoplasmic reticulum from rat ventral prostate. Mora \& Mahesh (1999) recently demonstrated the accumulation of AR mRNA in rat ventral prostate polyribosomes. It is possible that AR mRNA also accumulates in microsomes of adipose tissues and leads to the sequestering of AR that we observed in microsomes from omental adipose tissue. Alternatively non-classical subcellular distribution of

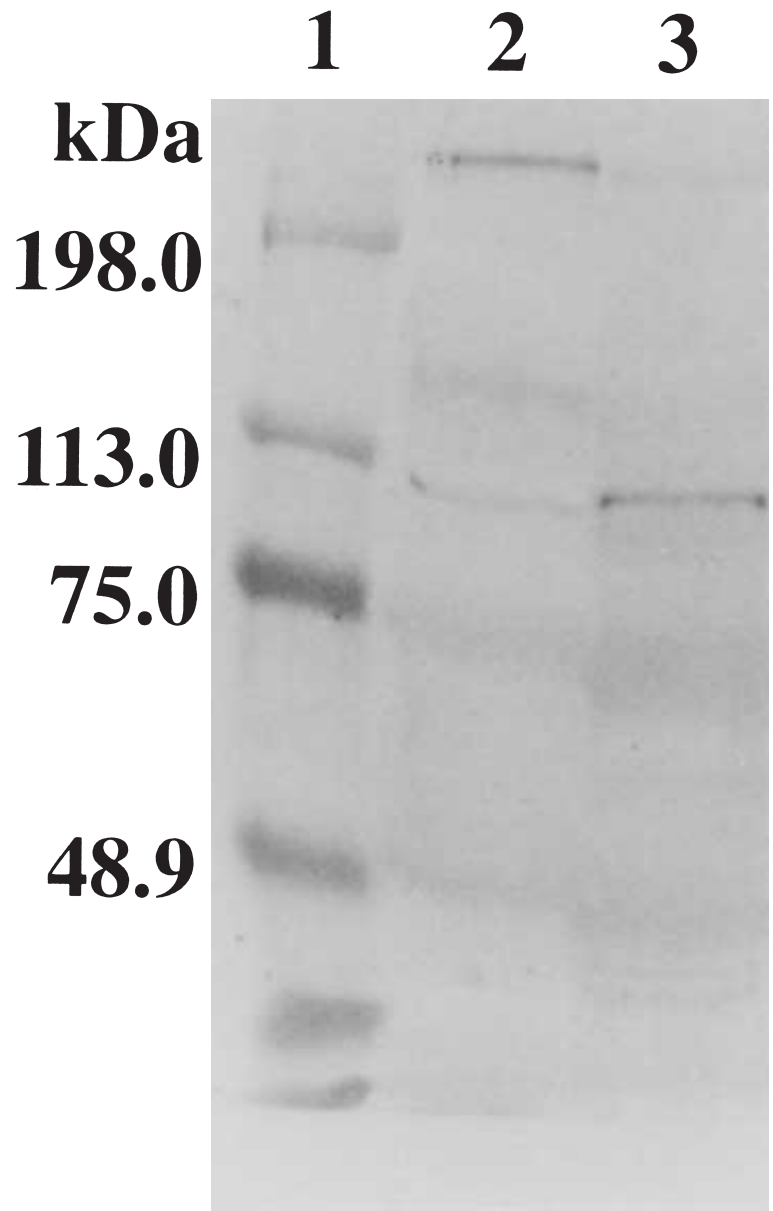

Figure 5 Treatment of glycoprotein fraction with endoglycosidase $\mathrm{F} / \mathrm{N}$-glycosidase $\mathrm{F}$ followed by Western blot analysis for AR.

Lane 1: prestained protein standards (broad range) with molecular weight on left. Lane 2: glycoprotein fraction $(410 \mu \mathrm{g}$ protein) from Con A column incubated without glycosidases. Lane 3: glycoprotein fraction $(410 \mu \mathrm{g}$ protein) from Con A column incubated with glycosidases.

steroid receptors has been associated with non-genomic actions of these hormones (Brann et al. 1995, Wehling 1997).

We noticed that the AR from the cytosolic fraction showed three isoforms with approximate molecular weights of 250, 140 and $110 \mathrm{kDa}$. When the cytosolic fraction or glycoprotein fraction from the Con A column was treated with endoglycosidase $\mathrm{F} / \mathrm{N}$-glycosidase $\mathrm{F}$, the 250 and $140 \mathrm{kDa}$ immunostaining bands decreased with an increase in the 110 and/or $104 \mathrm{kDa}$ bands. This was a strong indication that the 250 and $140 \mathrm{kDa}$ bands were glycosylated. To our knowledge, this is the first report of glycosylation of AR. However, the glycosylation of ER has been studied in some detail. Karthikeyan \& Thampan (1995) reported that non-activated ER bound to Con A and could be eluted with $\alpha$-methylglucoside. When the 
non-activated ER was treated with $\mathrm{N}$-glycopeptidase $\mathrm{F}$, it was deglycosylated to the nuclear ER R-II. They were also able to show that the purified non-activated ER stained for glycoprotein in Western blot analyses. The molecular weight of the glycosylated form was about the same as the deglycosylated form. Glycosylated ER, but not deglycosylated ER, dimerized with ER activation factor. The plasma membrane appears to be the primary site of localization of the glycosylated non-activated ER (Karthikeyan \& Thampan 1996). Jiang \& Hart (1997) reported a subpopulation of murine, bovine and human ERs that contained O-linked $\mathrm{N}$-acetylglucosamine and the O-glycosylation alternates with $O$-phosphorylation (Cheng et al. 2000). The glycosylation of AR that we observed in omental adipose tissue appears to be different from that reported for ER. Binding of AR to Con A and decrease in molecular weight when treated with endoglycosidase $\mathrm{F} / \mathrm{N}$-glycosidase $\mathrm{F}$ would suggest large $\mathrm{N}$-linked high mannose complex oligosaccharides. The sex steroid receptors may be synthesized as large glycoproteins, then the oligosaccharides are processed to form smaller units. Glycosylation of proteins is important in recognition markers, targeting, stability, storage or protein interactions and alterations of normal glycosylation patterns have been linked to several disease states (Dwek 1995). The function of glycosylation of AR and its role in obesity are unknown, and will have to be delineated by future experiments

A fourth band with an approximate molecular weight of $104 \mathrm{kDa}$ was sometimes observed in the cytosolic fraction. This band was particularly present after long incubations of the crude cytosolic fraction with endoglycosidase F/N-glycosidase F (Fig. 3). However, the $104 \mathrm{kDa}$ band was not seen when the glycoprotein fraction was treated with endoglycosidase F/N-glycosidase F (Fig. 5). These results would suggest that the $104 \mathrm{kDa}$ band could be a proleolytic degradation product. The increase in the $104 \mathrm{kDa}$ band as compared with control after treatment of the crude cytosolic fraction with endoglycosidase $\mathrm{F} / \mathrm{N}$ glycosidase F (Fig. 3) may be the result of the deglycosylated receptor being more readily degraded by proteasomes as has been reported for oligosaccharide-modified glycoprotein (Liu et al. 1999). Proteasome-mediated proteolysis of ER has been reported (Alarid et al. 1999, El Khissiin \& Leclercq 1999, Nawaz et al. 1999) and recently Sheflin et al. (2000) reported that inhibiting proteasomes increased the amount of AR in HepG2 and LNCAP cells. Some diffuse bands with molecular weights below $104 \mathrm{kDa}$ were often seen in the Western blots. Bands in this region are routinely seen in blots and often represent non-specific staining. When proteolysis is occurring, it would also be expected that fragments would show up in these areas which may cross-react with the antibody. However, quantification and tracking of fragments in this lower region is generally complicated due to lower antibody avidity and higher background due to broad non-specific staining.

\section{Acknowledgements}

We wish to thank Dr Geoffrey Greene, The Ben May Institute, The University of Chicago, Chicago, IL, USA for his gift of AR antibody (PG-21) and immunogen peptide and Dr M McPhaul, University of Texas Southwestern Medical Center, Dallas, TX, USA for his gift of two other AR antibodies, U407 and R489. This work was supported by grants from the Oklahoma Center for the Advancement of Science and Technology (7583612) (to G H W) and the Oklahoma Agricultural Experiment Station (CSRS-OKL 02058) (to J P M), and a Research and Development Award from the American Diabetes Association (to J P M).

\section{References}

Alarid ET, Bakopoulos N \& Solodin N 1999 Proteasome-mediated proteolysis of estrogen receptor: a novel component in autologous down-regulation. Molecular Endocrinology 13 1522-1534.

Bjorntorp P 1990 Classification of obese patients and complications related to the distribution of surplus fat. Nutrition 6 131-137.

Brann AW, Hendry LB \& Mahesh VB 1995 Emerging diversities in the mechanism of action of steroid hormones. Journal of Steroid Biochemistry and Molecular Biology 52 113-133.

Bray GA 1996 Health hazards of obesity. Endocrinology and Metabolism Clinics of North America 25 907-919.

Cheng X, Cole RN, Zaia J \& Hart GW 2000 Alternative O-glycosylation/O-phosphorylation of the murine estrogen receptor. Biochemistry 39 11609-11620.

Dwek RA 1995 Glycobiology: more functions for oligosaccharides. Science 269 1234-1235.

El Khissiin A \& Leclercq G 1999 Implication of proteasome in estrogen receptor degradation. FEBS Letters 448 160-166.

Husmann DA, Wilson CM, McPhaul MJ, Tilley WD \& Wilson JD 1990 Antipeptide antibodies to two distinct regions of the androgen receptor localize the receptor protein to the nuclei of target cells in the rat and human prostate. Endocrinology 126 2359-2368.

Jiang M \& Hart GW 1997 A subpopulation of estrogen receptors are modified by O-linked $\mathrm{N}$-acetylglucosamine. Journal of Biological Chemistry 272 2421-2428.

Karthikeyan N \& Thampan RV 1995 The nuclear estrogen receptor R-II of the goat uterus: Distinct possibility that the R-II is the deglycosylated form of the nonactivated estrogen receptor (naER). Archives of Biochemistry and Biophysics 321 442-452.

Karthikeyan N \& Thampan RV 1996 Plasma membrane is the primary site of localization of the nonactivated estrogen receptor in the goat uterus: hormone binding causes receptor internalization. Archives of Biochemistry and Biophysics 325 47-57.

Lewis DS, Masoro EJ \& Yu BP 1981 Isolation of plasma membranes from adipocytes. Methods in Enzymology 72 747-753.

Liu Y, Chaudhury P, Cabral M \& Sifers RN 1999 Oligosaccharide modification in the early secretory pathway directs the selection of a misfolded glycoprotein for degradation by the proteasome. Journal of Biological Chemistry 274 5861-5867.

McCann JP, Bergman EN \& Beermann DH 1992 Dynamic and static phases of severe obesity in sheep: feed intakes, endocrinology, and carcass and organ composition. Journal of Nutrition 122 496-505.

Mayes JS, McCann JP, Ownbey TC \& Watson GH 1996 Regional differences and up-regulation of progesterone receptors in adipose tissues from oestrogen-treated sheep. Journal of Endocrinology 148 $19-25$. 
Mora GR \& Mahesh VB 1999 Autoregulation of the androgen receptor at the translational level: testosterone induces accumulation of androgen receptor mRNA in the rat ventral prostate polyribosomes. Steroids 64 587-591.

Nawaz Z, Lonard DM, Dennis AP, Smith CL \& O'Malley BW 1999 Proteasome-dependent degradation of the human estrogen receptor. PNAS 96 1858-1862.

Pedersen SB, Fuglsig S, Sjogren P \& Richelsen B 1996 Identification of steroid receptors in human adipose tissue. European Journal of Clinical Investigation 26 1051-1056.

Prins GS, Birch L \& Greene GL 1991 Androgen receptor localization in different cell types of the adult rat prostate. Endocrinology 129 3187-3199.

Rebuffe-Scrive M, Cullberg G, Lundberg PA, Lindstedt G \& Bjorntorp P 1989 Anthropometric variables and metabolism in polycystic ovarian disease. Hormone and Metabolic Research 21 391-397.

Sheflin L, Keegan B, Zhang W \& Spaulding SW 2000 Inhibiting proteasomes in human HepG2 and LNCaP cells increases endogenous androgen receptor levels. Biochemical and Biophysical Research Communications 276 144-150.

Sjogren J, Li M \& Bjorntorp P 1995 Androgen hormone binding to adipose tissue in rats. Biochimica et Biophysica Acta 1244 117-120.

Steinsapir J, Evans AC Jr, McDonald T \& Muldoon TG 1990 Association of androgen binding sites with the endoplasmic reticulum of rat ventral prostate. Biology of Reproduction 42 337-349.
St John LC, Lunt DK \& Smith SB 1991 Fatty acid elongation and desaturation enzyme activities of bovine liver and subcutaneous adipose tissue microsomes. Journal of Animal Science 69 10641073.

Tchernof A \& Poehlman ET 1998 Effects of the menopause transition on body fatness and body fat distribution. Obesity Research $\mathbf{6}$ 246-254.

Vermeulen A, Goemaere S \& Kaufman JM 1999 Testosterone, body composition and aging. Journal of Endocrinological Investigation 22 110-116.

Watson GH \& Muldoon RE 1985 Specific binding of estrogen and estrogen-receptor complex by microsomes from estrogen-responsive tissues of the rat. Endocrinology 117 1341-1349.

Watson GH, Manes JL, Mayes JS \& McCann JP 1993 Biochemical and immunological characterization of oestrogen receptor in the cytosolic fraction of gluteal, omental and perirenal adipose tissues from sheep. Journal of Endocrinology 139 107-115.

Wehling M 1997 Specific, nongenomic actions of steroid hormones. Annual Review of Physiology 59 365-393.

York DA 1996 Lessons from animal models of obesity. Endocrinology and Metabolism Clinics of North America 25 781-800.

Received in final form 24 January 2001

Accepted 31 January 2001 